\title{
The Influence of Computer Attitude, Grade Point Average and Computer Self-Efficacy Against Computer Anxiety \\ ${ }^{1}$ Rahmansyah Nandang, ${ }^{2}$ Budiman
}

\author{
Program Magister Universitas Gunadarma, Depok -16424, Indonesia
}

Received: 16 May 2018; Accepted: 25 June 2019; Published: 08 September 2019

\begin{abstract}
Technological developments have rapidly become a global trend, which can be analyzed with specific activities are integrated using a computer to assist the work of man. Aware of the importance of mastering technology, preferably accounting teachers at the University emphasizes how important mastery of computers and software on most courses in order to equip the students so that they can increase their value in the business world. This research aims to confirm the influence of computer attitude, Grade Point Average, computer self efficacy against computer anxiety on University accounting majors Gunadarma. This research use 100 questionnaires as a method to acquire the datas. then the data were analyzed by using multiple linear regression analysis and data processed to get a positive result the existence of negative influence among computer attitude, grade point average, computer self-efficacy against computer anxiety.
\end{abstract}

Index Terms: Computer Attitude, Grade Point Average, Computer Self Efficacy, Computer Anxiety.

(C) 2019 Published by MECS Publisher. Selection and/or peer review under responsibility of the Research Association of Mode rn Education and Computer Science

\section{Introduction}

Rapid technological development has become a global trend, where it can be explored with the frequent variety of activities that are integrated using computer devices to help alleviate human work. The role of technology, especially computers, can be an added value for individuals who want to win competition in the world of work. Recognizing the importance of mastering technology in the world of work. Accounting teachers emphasize the importance of mastering computers and software, in order to equip students so that

* Corresponding author.

E-mail address: kumareshtce@gmail.com. 
they can increase their selling value in the world of work. These conditions directly affect the working patterns of accounting information systems.

To deal with the new development of information technology, one can respond to the presence of computers differently and not infrequently responded with rejection. This refusal may be caused by simple ignorance of computers or it may also be caused by deep anxiety or excessive fear of computer technology Jay[9] which is often referred to as "computerphobia" because new changes can cause stress. Pressure can be anxiety but some face it as a challenge. Anxiety is defined as a strong feeling of fear and concern that is not related to a particular threatening situation Wibowo and Hardiningsih[20].

Computer Anxiety is defined as the anxiety of computer use and anxiety about the negative effects of computer use on society Emmons[7], and many other researchers have found the phenomenon of computer anxiety. Computerized anxiety can be interpreted as a rejection of change. Rejection can be a symptom or something else such as fear of something unknown, fear of failure, or an unwillingness to change things now.

The results of previous studies by the Relationship between Computer Anxiety and Computer Self-Efficacy by Simsek[9] examined the relationship between Computer Anxiety and Computer Self-Efficacy in students and teachers in primary and junior secondary schools of the test.

People who are better at using computers can complete tasks faster would show that there is a negative correlation between computer anxiety on computer self-efficacy, Research Rifa., Et al., [14] on the Effects of Demographic and Personality Factors on Expertise in End-Using Computing Computer Attitude shows a person's reaction or judgment to a computer based on their pleasure or displeasure with computers. In other words, generally attitude shows the feeling of pleasure or displeasure of someone towards the stimulus object. The results of this study indicate that the discovery of a significant interaction between computer attitude, negatively affects computer phobia. Research Ali., Et al.,[4] concerning Computer Anxiety and Characteristics of Personality Types in Accounting Students. The results of this study show that there is no significant effect between Grade Point Average and Computer Anxiety.

Based on the above conditions, this opportunity examined the influence of Computer attitude, Grade Point Average and Computer self-efficacy on computer anxiety on accounting students at the 2014 Gunadarma University.

\section{Objective}

The main objective of this research is student majoring in accounting at Gunadarma University in 2014.

\section{Significance}

Get empirical evidence that there is a influence between computer attitude, grade point average and self-efficacy computer against computer anxiety partially and together in accounting department students at Gunadarma University.

\section{Research Methodology}

In this research, the object which is used as research is the student/College of accounting department at a private university namely Gunadarma University located on Jl. Margonda Raya No. 100, Pondok Cina, Depok research was conducted in 2015 sixth term undergraduate accounting students. This research uses quantitative approaches with data collection methods through interviews and questionnaires. Data collection results of questionnaires in the application of SPSS version 20, tabulation data is used to calculate each indicator several indicators used are Computer Anxiety, Computer Attitude, Grade Point Average, Computer Self-Efficacy. To process the data on the indicators using the classic test assumption method, questionnaire test, and hypothesis 
test to determine the effect of Computer Attitude, Grade Point Average, Computer Self-Efficacy against Computer Anxiety

\section{i. Existing Methods and Analysis}

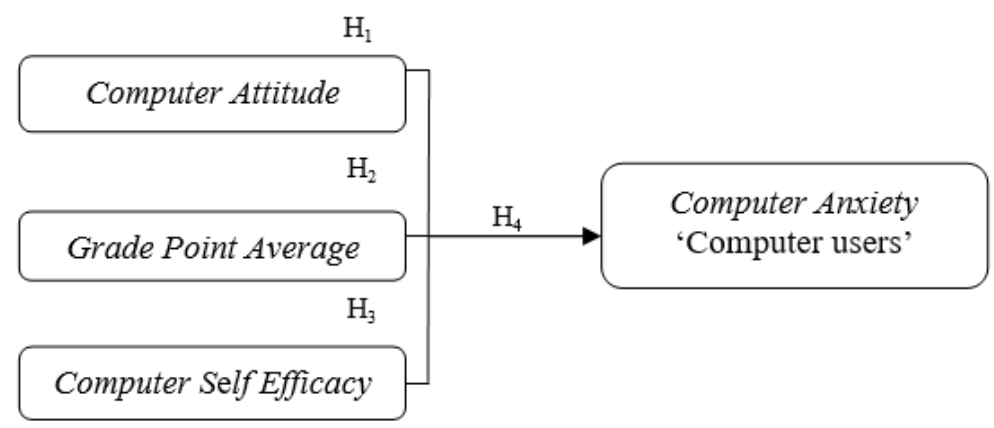

Fig.1. Theoretical thinking frameworks for the influence of computer attitude, grade point average and computer self-efficacy against computer anxiety

- H1: Computer anxiety levels in accounting students will vary according to their Computer Attitude.

- H2: Computer anxiety levels in accounting students will vary according to their Grade Point Average.

- H3: Computer anxiety levels in accounting students will vary according to their Computer Self Efficacy.

- H4: The influence of the together between Computer Attitude, Grade Point Average, and Computer Self Efficacy against Computer Anxiety in accounting students

\section{ii. Experimental Results and Analysis}

Table 1. Multiple linear regression analysis for the influence of computer attitude, grade point average and computer self-efficacy against computer anxiety

Coefficients $^{\mathrm{a}}$

\begin{tabular}{|l|r|r|r|}
\hline \multirow{2}{*}{ Model } & \multicolumn{2}{|c|}{$\begin{array}{c}\text { Unstandardized } \\
\text { Coefficients }\end{array}$} & $\begin{array}{c}\text { Standardized } \\
\text { Coefficients }\end{array}$ \\
\cline { 2 - 4 } & \multicolumn{1}{|c|}{$\mathrm{B}$} & \multicolumn{1}{c|}{ Std. Error } & \multicolumn{1}{c|}{ Beta } \\
\hline $1 \quad$ (Constant) & 50.780 & 9.279 & \\
Computer_Attitude & -.508 & .237 & -.208 \\
Grade_Point_Average & 1.103 & 1.515 & .070 \\
Computer_self_efficacy & -.440 & .163 & -.263 \\
\hline
\end{tabular}

a. Dependent Variable: Computer_Anxiety

$$
\bar{Y}=\alpha+\beta_{1} \chi_{1}+\beta_{2} \chi_{2}+\beta_{3} \chi_{3}+\varepsilon
$$


Where:

$$
\begin{aligned}
& \bar{Y}=\text { Computer Anxiety } \\
& \chi_{1}=\text { Computer Attitude } \\
& \chi_{2}=\text { Grade Point Average } \\
& \chi_{3}=\text { Computer Seft Efficacy } \\
& \beta_{1,} \beta_{2,} \beta_{3}=\text { Regression coefficient } \\
& \alpha=\text { Coefficient of constants }
\end{aligned}
$$

$$
\bar{Y}=50.780-0.508 \chi_{1}+1.103 \chi_{2}-0.440 \chi_{3}+\varepsilon
$$

Figure 50.780 indicates that the value of Computer Anxiety $(\bar{Y})$ is 50.780 with no influence from Computer Attitude $\left(\chi_{1}\right)$, Grade Point Average $\left(\chi_{2}\right)$, and Computer Self Efficacy $\left(\chi_{3}\right)$. The value of variable regression coefficient obtained for Computer Attitude $\left(\chi_{1}\right)$ is 0.508 . This shows that every increase in the Computer Attitude of one unit, then will be followed by a decrease in Computer Anxiety level of -0.508 units and vice versa each unit of decline in Computer Attitude will be followed also With increased Computer Anxiety of -0.508 units with other variables assumptions such as Grade Point Average $\left(\chi_{2}\right)$ and Computer Self Efficacy $\left(\chi_{3}\right)$.

The value of the variable regression coefficient obtained for Grade Point Average $\left(\chi_{2}\right)$ is 1.103 . This indicates that each enhancement of the Grade Point Average of one unit, then will be followed by an increase in the level of Computer Anxiety of 1.103 units and vice versa any one unit reduction over the Grade Point Average will be followed with the decrease of Computer Anxiety amounted to 1.103 units assuming other variables such as Computer_Attitude $\left(\mathrm{X}_{1}\right)$ and Computer Self Efficacy $\left(\chi_{3}\right)$. This shows that students with a Grade Point Average value of 3.0 and above are not severely influenced by computer anxiety

The value of the variable regression coefficient obtained for Computer Self Efficacy $\left(\chi_{3}\right)$ is -0.440 . This indicates that every upgrade over Computer Self Efficacy $\left(\chi_{3}\right)$. By one unit, it will be followed by a decrease in Computer Anxiety level of -0.440 units and vice versa of any single unit drop over Computer Self Efficacy $\left(\chi_{3}\right)$. It will also be followed by increasing Computer Anxiety of -0.440 units with the assumption of other variables such as Computer Attitude $\left(\chi_{1}\right)$ and Computer Self Efficacy $\left(\chi_{3}\right)$.

The default Error (e) is the maximum value of an error that can occur in estimating the average population based on a sample. Because multiple linear regression tests are used to find a significant look at independent variables against dependent variables then we only focus on the Beta columns in the Unstandarized Coefficients table and the significance column due to the beta coefficient Used to see the importance of each relative independent variable, so that the error standard does not need to be invoked. 


\section{Observation and Discussion}

This research illustrates the observation in four aspects, namely the effect of Computer Attitude on Computer Anxiety, the effect of Grade Point Average on Computer Anxiety, Computer Self Efficacy influence on Computer Anxiety, influence Computer Attitude, Grade Point Average, Computer Self Efficacy together against Computer Anxiety observation on various datasets presented for experimental validation.

\section{i.Computer Attitude influence on Computer Anxiety}

Based on the results of the study, individually computer Attitude has a negative influence and significant effect on computer Anxiety in Accounting college student Gunadarma University It is shown with a value of $-t_{\text {test }}<t_{\text {table }}(-2.245<1.660)$ and the significance in the $T_{\text {test }}$ is less than $0.05(0.034<0.05)$ then the $\mathrm{H}_{0}$ in decline, the student have an optimistic tendency to use the computer. In the description of the lowest score variable is on the 2 nd statement, that is about the computer makes me uncomfortable because I could not use it with a total score of 103. This is so long as students are uncomfortable in using because the factor can not operate, while the highest score is on the 20th statement, that is about me difficult to work using a computer with a total score of 138. From the research results the higher the value of Computer Attitude decreases Computer Anxiety influence in students, because the higher the comfort of students in using computers on daily life then the lower the level Anxiety in the use of computers in daily life, it supports the previous research on the influence of computer Attitude on Computer Anxiety conducted by Adebowale[1], Purnomo[13], Igbaria[8,19], Nickell[10] and Afriana[2], there is a Significant influence between computer attitude towards skill in using computer. Students with a comfortable or uncomfortable attitude towards computer use can affect daily computer use.

Referring to the attitude indicated by the respondent in this study, the result of Computer Attitude calculation against Computer Anxiety on the questionnaire showed that respondents tend to be pessimistic in computer use.

\section{ii. Grade Point Average influence on Computer Anxiety}

Based on the results of the study, partial Grade Point Average does not affect the Computer Anxiety in Accounting college student Gunadarma University It is shown with the value of $t_{\text {test }}<t_{\text {table }}(0.728<1.660)$ and the significance of the $T_{\text {test }}$ more large of $0.05(0.468>0.05)$ then the $\mathrm{H}_{0}$ in the accepted that means no influence between the Grade Point Average with Computer Anxiety. Based on the results obtained in the description of the lowest score variable is found in the alignment with the value of Grade Point Average 0-2.00, which is 0 respondents. This means that the student Department of Accountancy no one has a Grade Point Average 0-2.00, while the highest score is found in the statement with the value of Grade Point Average 3.01-3.50, which is of 220 so long as the student Department of Accounting largely Has a Grade Point Average value of 3.01-3.50. But in the use of computer Grade Point Average value on students majors of accounting do not influence each other because in students with the Grade Point Average 0-2.00 Less concerned in the use of computers on daily life, but the student with the Grade Point Average 3.01-3.50 cares about the use of computers in everyday life but lack of expertise is the cause of students anxious to use the computer. It supports previous research on the influence of Grade Point Average on Computer Anxiety conducted by Syaiful[3], B. Kannan[5], and Sam[16]. The experience of using a computer has a strong relationship with computer anxiety. So that students who have high Grade Point Average is not necessarily more often using computers compared to students who have lower Grade Point 
Average, and has no impact on the level of anxiety in computing a computer among students who have high Grade Point Average with students who have lower Grade Point Average.

\section{iii. Computer Self Efficacy influence on Computer Anxiety}

Based on the results of the study, it is shown with a value $-t_{\text {test }}<t_{\text {table }}(-2.703<1.660)$ and the significance in $T_{\text {test }}$ is less than $0.05(0.008<0.05)$ then the $\mathrm{H}_{0}$ in the decline. In the description of the lowest score variable is on the 2nd statement, I can get the job done using the package program (software), if I have not used the software package like that before. With a total score of 257. It means that students are not confident in completing all the tasks that use the computer although the student have not used the software, while the highest score is on the 1st statement, namely I can finish the job using the package program (software), if no one around me tells me what to do with the total score of 320. Therefore, individually computer Self Efficacy has a negative influence and significant effect on computer Anxiety in Accounting college student Gunadarma University. The result of the study above can be concluded that the higher the value of Computer Self Efficacy in the student then the less influence Computer Anxiety on students, this is because the higher confident students in using Computer on daily life hence the diminishing influence of anxiety in the use of computers on daily life. This supports previous research on Computer Self Efficacy influence on Computer Anxiety conducted by Nur'ain Achim[11,17]The main factor affecting Computer Self Efficacy against Computer Anxiety is Because of the lack of updates of computer technology in daily life. These results were also reinforced by several empirical results of previous research conducted by Simsek[18], Campeau[6], Agarwal [3,15] and Parasara[12] who also supported the results of this study.

\section{iv. Influence Computer Attitude, Grade Point Average, Computer Self Efficacy together against Computer} Anxiety

Based on the results of the research, Computer Attitude, Grade Point Average, and Computer Self Efficacy have positive and significant effect on Computer Anxiety in accounting students at Gunadarma University. It is indicated by $F_{\text {test }}>F_{\text {table }}(5.151>3.09)$ and the significance is less than $0.05(0.002<0.05)$ then $\mathrm{H}_{0}$ in the decline. This means Computer Attitude has a thorough negative influence on Computer Anxiety in students, in addition to Computer Attitude, Grade Point Average can also affect the level of Computer Anxiety on students in the use of computers, in addition Grade Point Average, Computer Self Efficacy is another important element that can negatively affect Computer Anxiety in student. All three independent variables are related and mutually affecting one another.

\section{Conclusion}

Based on the results of the research conducted, the following analyses and recommendations that have been submitted earlier, can be concluded as follows:

1. Based on the results of the research, it can be noted that Computer Attitude, Grade Point Average, Computer Self Efficacy has a significant relation and influence on Computer Anxiety, therefore it is expected to the University of Gunadarma to be more often Use the computer to provide lecture materials and assignments to students. It can also be applied by other universities of the same type.

2. This research is expected to be a reference to develop similar research in the future, this model of research can be developed by adding other variables that affect Computer Anxiety, such as locus of control, gender, Individual innovativeness or organization support, and samples of students from other majors or the general public, so that this research can be more commonly used. 


\section{Acknowledgement}

The authors would like to acknowledge the support provided by the affiliated colleges under University Gunadarma for providing a valuable dataset of the institutions to carry out the research study.

\section{References}

[1] Adebowale, O.F, Adediwura, A.A., and Bada, T. A., 2009 Correlates of Computer Attitude among Secondary School Students in Lagos State, Nigeria. International Journal of Computing and ICT Research, 3, (2) 20 - 30.

[2] Afriana Cahyandari . 2009. Pengaruh Computer Anxiety dan Computer Attitude terhadap keahlian karyawan bagian akuntansi dalam menggunakan komputer (survey pada PT PLN (Persero) Distribusi Jakarta Raya dan Tangerang Khusus area pelayanan dan area jaringan). Skripsi (tidak dipublikasikan). Fakultas Ilmu Sosial dan Ekonomi. Universitas Negeri Yogyakarta. Yogyakarta.

[3] Agarwal, Rithu, V. Sambamurthy and R.M. Stair, 2000, Research Report: The Solving Relationship between General and Specific Computer Self Efficacy - An Empirical Assessment, Information Systems Research, Vol. 11, No. 4. Minnesota.

[4] Ali, Syaiful, \& Fadilah. 2008. "Kecemasan Berkomputer (Computer Anxiety) dan Karakteristik Tipe Kepibadian Pada Mahasiswa Akuntansi." Simposium Nasional Akuntansi XI. Pontianak.

[5] B. Kannan, A. Muthumanickam and S. Chandrasekaran. 2012. Computer Anxiety Among Higher Secondary Students. International Journal of Development Research, 2,( 4),1008-1011.

[6] Campeau, Deborah \& Hinggis, 1995, Computer Self Efficacy: Development of Measure and Initial Test, MIS Quartely, Vol 19 No. 12.

[7] Emmons, B. A. 2003. Computer Anxiety, Communication Preferences, and Personality Type in the North Carolina Cooperative Extension Service. Unpublished doctoral dissertation, North Carolina State University.

[8] Igbaria, M and Parasuraman, S., 1989. "A Path Analytic Study of Individual Characteristics, Computer Anxiety, and Attitudes Toward Microcomputer",Jurnal of Management, Vol. 15, No. 3.

[9] Jay, T.B. 1981 Computerphobia: What to do about it. Educational Technology, 21,47-48.

[10] Nickell, G. S., \& Pinto, J. N. 1986. The computer attitude scale. Computers in Human Behavior, 2, 301-306.

[11] Nur'ain Achim, Arraqib Al Kassim 2014. Computer usage: the impact of computer anxiety and computer self efficacy. Global Conference on Business \& Social Science-2014. Kuala Lumpur.

[12] Parasara, Anak Agung Putra. 2014. "Pengaruh Computer Anxiety pada Computer Self Efficacy". E-Jurnal Akuntansi Universitas Udayana. Bali: Universitas Udayana.

[13] Purnomo Wahyu Joko. 2010. Pengaruh Computer Anxiety dan Computer Attitude Terhadap Keahlian Pegawai Bagian Akuntansi Dalam Menggunakan Komputer (Studi kasus pada Dinas Pendapatan, Pengelolaan Keuangan dan Aset Daerah Kabupaten Wonogiri). Skripsi (tidak dipublikasikan). Fakultas Ilmu Sosial dan Ekonomi. Universitas Negeri Yogyakarta. Yogyakarta.

[14] Rifa, D., \& Gudono. 1999. Pengaruh Faktor Demografi dan Personality terhadap keahlian dalam End User Computing. Jurnal Riset Akuntansi Indonesia, 2(1),20-36.

[15] Rustiana, 2004, Computer Self Efficacy (CSE) Mahasiswa Akuntansi Dalam Penggunaan Teknologi Informasi: Tinjauan Perspektif Gender, Jurnal Ekonomi Akuntansi, Vol 17, No. 1, Maret.

[16] Sam, H. K., Othman, A. E. A., \&Nordin, Z. S. 2005. Computer Self-Efficacy, Computer Anxiety, and Attitudes toward the Internet: A Study among Undergraduates in Unimas. Educational Technology \& Society, 8 (4), 205-219.

[17] Setyomurni, Retno dan Tony Wijaya, pp.2009."Pengaruh Computer Anxiety terhadap Keahlian Novice 
Accountant dalam Menggunakan Komputer: Gender dan Locus Of Control sebagai Faktor Moderasi" Jurnal Akuntansi Manajemen. Yogyakarta.

[18] Simsek, Ali. 2011. The Relationship Between Computer Anxiety And Computer Self-Efficacy.Contempory Educational Technology, 2 (3), pp. 177-187.

[19] Trisnawati, Rina dan Shinta Permatasari. 2000. "Pengaruh Faktor Personality Terhadap Keahlian Karyawan Dalam Menggunakan Komputer". Emperika, No. 26, Desember. 83-93

[20] Wibowo, T., \& Hardiningsih, P. 2003. Pengaruh Faktor Personality dan Profesional Commitment terhadap Keahlian Computer Audit. Jurnal Bisnis dan Ekonomi. Maret.

\section{Authors' Profiles}

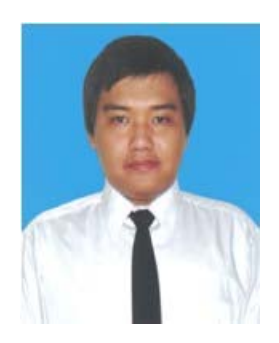

Rahmansyah Nandang is a student in a Gunadarma University. He hold diploma in computer science in Gunadarma University, his area of interested research in human resource information system, IT infrastructure and system information.

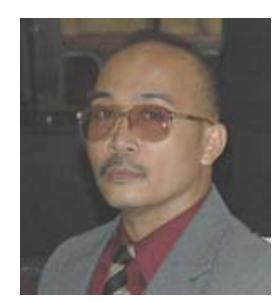

Budiman is a lecture in a Gunadarma University. he hold diploma in Hasanuddin University, graduated master in Bogor Agricultural Institute and doctorate in Gunadarma University, his area of interested research in Micro funds struggle research through micro-credit group for Community Empowerment .

How to cite this paper: Rahmansyah Nandang, Budiman. "The Influence of Computer Attitude, Grade Point Average and Computer Self-Efficacy Against Computer Anxiety", International Journal of Education and Management Engineering(IJEME), Vol.9, No.5, pp.10-17, 2019.DOI: 10.5815/ijeme.2019.05.02 